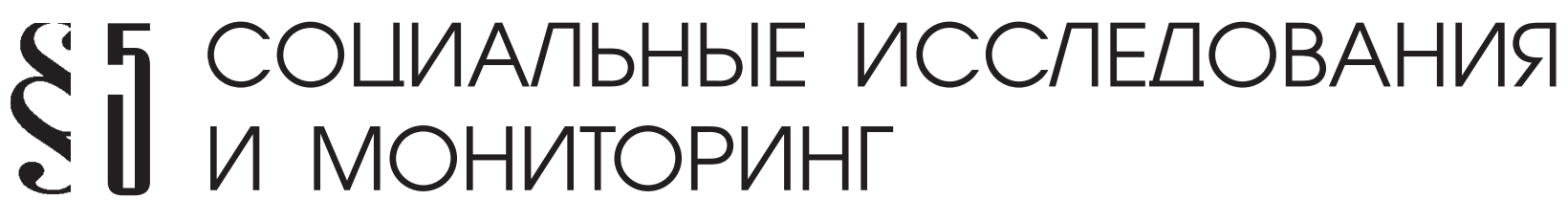

Миронова Ю.В.

\section{ПРАВОВОЙ НИГИЛИЗМ КАК ФАКТОР ПОВЫШЕНИЯ ЭФФЕКТИВНОСТИ ЗАКОНОДАТЕЛЬСТВА}

\begin{abstract}
Аннотация: $B$ данной статье указывается на необходимость обязательного учета общественного мнения 8 процессе законотворчества. Любой закон, а также правопорядок в челом, осмысливается каждым человеком с помощью правосознания, по своей структуре разделенного на три уровня, от повыщения которых зависит степень правосознания и уровень правовой культуры каждого человека. Основной проблемой правосознания выступает его деформация, выраженная в различных формах, в том числе и правового нигилизма.

Review: The author of the article points out how necessary it is to take into account the public opinion in the law making process. Each law in particular and legal order in general are considered by each person through legal sense. The structure of legal sense has three levels defining each individual's degree of legal sense and legal culture. The main problem here is the deformation of legal sense that can take different forms including law nihilism.
\end{abstract}

Ключевые слова: Юриспруденция, общество, правосознание, нигилизм, деформация, мониторинг, интересы, закон, право, правотворчество

Keywords: law studies, society, legal sense, nihilism, deformation, monitoring, interests, law, right, law making process.

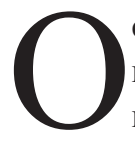
сновным оценочным критерием любого законодательного акта выступает его результативность, выраженная в реальной работе закона, достижения поставленных перед ним целей и того, насколько принятый законодательный акт отвечает требованиям и интересам большинства членов общества.

Качественный и эффективный закон, а также установленный правопорядок в целом, находят свое отражение в обществе через состояние правосознания каждого индивида, групп людей, а также всего населения. Ведь благодаря наличию правосознания каждый человек способен реагировать и давать оценку тем правовым регламентациям, которые затрагивают его взаимоотношения в обществе.

Любой закон принимается для и во имя человека, и законодатель, подготавливая тот либо иной проект нормативного правового акта, не имеет права пренебрегать мнением тех, кого может коснуться будущий закон. Именно поэтому основным элементом юридической стратегии принятия нормативно-правового акта выступает мониторинг общественного мне- ния, заключающийся в выяснение основных проблем, связанных с тематикой будущего закона, а также обязательный учет мнения каждого индивида по принимаемому нормативно-правовому акту, с тем, чтобы сделать его качественным, работающим и, по возможности, неуязвимым. Нельзя не согласиться с тем, что без наличия правосознания, а желательно его высокого уровня, сделать это не представляется возможным.

С точки зрения принятия нормативно-правовых актов, касаясь вопроса правосознания, представляется необходимым остановиться на вопросе, касающемся его структуры, исходя из глубины познания правовых явлений его субъектом.

Общая теория права, основываясь на результатах изучения сознания философией, ограничивается в исследовании правосознания двумя уровнями: обыденным и теоретическим (рациональным) ${ }^{1}$. Однако, на наш взгляд, не менее важным является такой уровень

\footnotetext{
${ }^{1}$ См.:напр.: Проблемы общей теории права и государства
} / Под. ред. В.С. Нерсесянца. - М., 1999. - С. 384 - 386. 


\section{Политика и общество $7(103) \cdot 2013$}

сознания, как практическое правосознание, играющее важную роль в общественной жизни, и влияющее на процессы правового регулирования.

Все три обозначенных уровня действуют системно и оказывают существенное воздействие на правотворческую и правореализующую деятельность. Исследование правосознания необходимо проводить в единстве всех трех уровней. Только тогда изучение правосознания приобретет научный характер и будет успешно использовано в процессе законотворчества, а также существенно повысит правовую культуру населения.

Обыденное правосознание отражает интересы людей, возникающие в их непосредственном общении друг с другом, что необходимо в процессе создания и реализации норм права. Но правотворчество и правореализация не будут эффективными, если они не опираются на практическое правосознание, обладающее опытом воздействия на реальные общественные отношения. Высшим уровнем правосознания выступает теоретический уровень сознания. Именно он способствует определению и осмыслению путей развития регулируемых правовыми нормами общественных отношений в процессе правотворчества и правореализации. С помощью научных и доктринальных знаний на теоретическом уровне правосознания воспроизводятся и преобразуются накопленные ценностные ориентации обыденного или практического правосознания.

Главной особенностью правового сознания является его аккумулирование всех трех уровней правосознания в их диалектическом единстве.

Интеграция обыденного, практического и теоретического правосознания активно влияет на процесс правотворчества. И если обыденное правосознание, реагирующее на потребности общественной жизни, концентрирует внимание законодателя на проблемах, возникающих в той или иной сфере жизнедеятельности, то на уровне практического правосознания происходит анализ выявленных проблем и возникает актуализация необходимости регулирования данных отношений нормами права. И впоследствии, опираясь на накопленный опыт обыденного и практического уровней, правосознание осмысливается с точки зрения научных доктрин и поднимается на самую высокую ступень своего развития. На теоретическом уровне осуществляется более осмысленная и глубокая оценка нормативного правового акта, ведь именно наличие научных доктринальных знаний позволяет субъекту правосознания подойти к вопросу принятия закона с позиции объективности и рационализма.
Однако правосознание по своей структуре содержит не только рациональный, но и психологический компонент, то есть каждый субъект правосознания, будь, то индивид, группа лиц или общество, не только накапливает полученные знания, но и, исходя из своего опыта и сложившихся стереотипов, дает собственную оценку полученных знаний в области права. И именно здесь возникает основная, с точки зрения большинства ученых, проблема, связанная с правосознанием - его деформация.

В силу сложившихся жизненных обстоятельств, субъект начинает неадекватно оценивать нормативно-правовой акт, а подчас и весь правопорядок в целом, что приводит к деформации его правосознания, которое в свою очередь может выразиться в различных формах: правового фетишизма, правового инфантилизма и правового нигилизма. Если правовой фетишизм, как явление, при котором ценность права, либо закона преувеличивается, встречается достаточно редко, то остальные две формы деформированного правосознания в той или иной степени наблюдаются практически у каждого субъекта правосознания.

Выделяют три основные формы правового инфантилизма: незнание права (правовая неграмотность), правовая безответственность и правовая пассивность ${ }^{2}$. То есть инфантильное правовое сознание может иметь различную степень дефективности - от незначительных пробелов в правовых знаниях и оценках до полной несформированности всех уровней его функционирования. При этом решающее значение имеет несформированность познавательного и оценочного уровней, что создает достаточные предпосылки дисфункции правового сознания в целом. Правовой нигилизм же, имея более глубинную форму познания правовой действительности, выражается в отрицании права либо конкретного закона, по мнению того либо иного субъекта правосознания, ввиду его нерезультативности.

И.И. Карпец, А.Р. Ратинов считают, что правовой инфантилизм представляет собой «наиболее мягкую форму искажения правового сознания и заключается в недостаточной сформированности и пробельности правовых взглядов, знаний, установок, представлений» ${ }^{3}$.

\footnotetext{
2 Каландришвилли 3.Н. Деформация правового сознания молодежи и юридические способы ее преодоления. Дисс. ... канд. юрид. наук. - Санкт-Петербург, 2004. - С. 45.

${ }^{3}$ Карпец И.И., Ратинов А.Р. Правосознание и причины преступности // Советское государство и право. 1968. №12. - C. 50 .
} 
Этого же мнения придерживаются П.П. Баранов ${ }^{4}$, В.В. Сорокин ${ }^{5}$, В.Р. Петров ${ }^{6}$, 3.Н. Каландашвили ${ }^{7}$.

Однако с точки зрения принятия нормативно-правовых актов указанный взгляд на проблему представляется нам ошибочным. Мы говорили о том, что высокая степень правосознания, и как следствие повышение эффективности принятия закона, зависит непосредственно от наличия трех уровней правосознания: теоретического, практического и обыденного. Что касается правового инфантилизма, то в данном случае речь идет только о наличии обыденного и практического уровней, причем даже здесь мы видим отсутствие объективного отражения правовой действительности. Что опаснее для общества и правопорядка: когда индивид обладает знаниями в правовой области и выражает отрицательную их оценку, либо вообще не знает и не хочет знать права и закона? Нам представляется, второе. Возьмем конкретный пример из области избирательного права: в одном случае индивид не является на выборы ввиду полной правовой безграмотности и пассивности в правовой сфере (правовой инфантилизм), либо является на избирательный участок, заполняет бюллетень, выражая отрицательное отношение к поставленному перед ним вопросу. И возвращаясь к мониторингу общественного мнения: какую правовую оценку может дать в своем опросе носитель правового инфантилизма? Никакую. Правовой нигилист же наоборот не только выразит свое отрицательное отношение к обсуждаемому нормативно-правовому акту, но и, вполне вероятно, предложит свое видение решения данной проблемы.

Изучая проблематику правового нигилизма, конечно, нельзя не учитывать отрицательные стороны данного явления, результатом которого может быть не

\footnotetext{
${ }^{4}$ Баранов П.П. Профессиональное правосознание работников ОВД. Теоретические проблемы. - М., 1991. - С. 83.

5 Сорокин B.B. Правосознание в переходный период общественного развития // Журнал российского права. 2002. № 10. - C. 67.

${ }^{6}$ Петров В.Р. Деформация правосознания граждан России. (Проблемы теории и практики): Дисс. ... канд. юрид. наук. Н.Новгород, 2000. - С. 45.

${ }^{7}$ Каландашвили 3.Н. Деформация правового сознания молодежи и юридические способы ее преодоления: теоретико-правовой аспект: Автореф. дисс. ... канд. юрид. наук. Санкт-Петербург, 2004. - С. 12.
}

только игнорирование закона, коррупция, но и совершение правонарушений.

В настоящее время понятие нигилизма наполняется только негативным содержанием. Под нигилизмом понимают отрицание общепризнанных ценностей. Это одна из форм мироощущения и социального поведения ${ }^{8}$.

По мнению Р.А. Кузнецова, деформация правового сознания в конкретный период развития того или иного общества может выступать и выступает только как негативное социальное явление 9 . Связано это с тем, что она является отражением возникающих в обществе противоречий между людьми, приводит к социальной нестабильности и сказывается на состоянии законности в стране.

Напрашивается вывод о том, что правовой нигилизм это, безусловно, отрицание ценности права. Но можно ли назвать правовым нигилизмом правотворческую деятельность законодателя, когда отменяется, по существу отрицается, один закон и принимается другой? Возможно, мы имеем дело с прогрессивным значением нигилизма? Следовательно, отрицание закона не всегда есть форма проявления отрицательных, негативных, регрессивных начал правового нигилизма.

В.Н. Кудрявцев, например, считает недопустимым отрицание любого закона, поскольку это ведет к анархии и опасности. Причем, эта опасность будет заключаться в том, что игнорировать закон под флагом «истинного права» будут все те, кому мешают правопорядок и законность, демократия и гуманизм ${ }^{10}$.

Однако еще Аристотель писал о том, что каждый закон государства опирается на, своего рода, право справедливость, разум, природу. Но и за несправедливыми законами Аристотель признает обязательную силу. Преодоление отрицательных последствий закона Аристотель называет правдой ${ }^{11}$. Как видим, Аристотель, признавал силу позитивного закона, но его исполнение ставил под сомнение.

\footnotetext{
${ }^{8}$ Радьков О.С. Правовой нигилизм в России. Дисс. ... канд. юрид. наук. - Ростов-на-Дону, 2005. - С. 28.

9 Кузнецов Р.А. Деформация профессионального правосознания юристов. Дисс. ... канд. юрид. наук. - Екатеринбург, 2005. - C. 36.

${ }^{10}$ См.: Кудрявцев В.Н. О правопонимании и законности // Государство и право. 1994. №3. - С. 5, 6.

${ }^{11}$ См.: Нерсесяни В.С. Политические учения Древней Греции. - М., 1979. - С. 208-211.
} 


\section{Политика и общество $7(103) \cdot 2013$}

Правовой нигилизм «способствует» прогрессивному развитию позитивного права в государстве - полагал русский философ И.А. Ильин. Он отмечал, что «постепенное развитие положительного права состоит в том, что «устарелые» нормы отменяются, а на их место устанавливаются новые. Норма считается устарелою или тогда, когда прежний общественный уклад уступил свое место новому, или тогда, когда нравственное чувство людей стало более глубоким и верным и перестало удовлетворятся старым правом» ${ }^{12}$.

Таким образом, мы полагаем, что, несмотря на очевидную опасность и пафос отрицания права, его принципов, нигилистические тенденции в юридической теории и практике являются существенным фактором развития общества, поскольку способствуют высвобождению и проявлению созидательных сил и, при известных обстоятельствах, способствуют прогрессу.

Нельзя не отметить и тот факт, что наличие той или иной формы деформированного правосознания каждого конкретного индивида свидетельствует о его отношении к правовой политике государства в целом, и это отношение по своей сути не обязано быть строго положительным. Через призму деформированного правосознания довольно легко можно охарактеризовать состояние эффективности и качества того правопорядка, которое царит в том либо ином государстве. То есть наличие деформированного правосознания содержит в себе положительный момент, так как выступает в роли своеобразного критического отклика к действующему в государстве законодательству и праву в целом.

Мы можем наблюдать довольно цикличный процесс - эффективный закон может повлиять на повышение уровня правосознания и правовой культуры в обществе, так же как и высокая степень правосознания оказывает существенное влияние на процесс законотворчества.

\section{Библиография:}

1. Баранов П.П. Профессиональное правосознание работников ОВД. Теоретические проблемы. - М., 1991.

\footnotetext{
${ }^{12}$ Цитируется по: Тихонравов Ю.В. Основы философии права. Учебное пособие. - М.: Вестник, 1997. - С.73.
}

2. Каландришвилли 3.Н. Деформация правового сознания молодежи и юридические способы ее преодоления. Дисс. ... канд. юрид. наук. - СанктПетербург, 2004.

3. Карпец И.И., Ратинов А.Р. Правосознание и причины преступности // Советское государство и право. 1968. №12.

4. Кудрявцев В.Н. О правопонимании и законности // Государство и право. 1994. №3.

5. Кузнецов Р.А. Деформация профессионального правосознания юристов. Дисс. ... канд. юрид. наук. - Екатеринбург, 2005.

6. Нерсесянц В.С. Политические учения Древней Греции. - М., 1979.

7. Петров В.Р. Деформация правосознания граждан России. (Проблемы теории и практики): Дисс. ... канд. юрид. наук. - Н.Новгород, 2000.

8. Проблемы общей теории права и государства / Под. ред. В.С. Нерсесянца. - М., 1999.

9. Радьков О.С. Правовой нигилизм в России. Дисс. ... канд. юрид. наук. - Ростов-на-Дону, 2005.

10. Сорокин В.В. Правосознание в переходный период общественного развития // Журнал российского права. 2002. № 10.

11. Тихонравов Ю.В. Основы философии права. Учебное пособие. - М.: Вестник, 1997.

\section{References (transliteration):}

1. Baranov P.P. Professional'noe pravosoznanie rabotnikov OVD. Teoreticheskie problemy. - M., 1991.

2. Kalandrishvilli Z.N. Deformaciya pravovogo soznaniya molodezhi i yuridicheskie sposoby ee preodoleniya. Diss. ... kand. yurid. nauk. - Sankt-Peterburg, 2004.

3. Karpec I.I., Ratinov A.R. Pravosoznanie i prichiny prestupnosti // Sovetskoe gosudarstvo i pravo. 1968. №12.

4. Kudryavcev V.N. O pravoponimanii i zakonnosti // Gosudarstvo i pravo. 1994. №3.

5. Kuznecov R.A. Deformaciya professional'nogo pravosoznaniya yuristov. Diss. ... kand. yurid. nauk. Ekaterinburg, 2005.

6. Nersesyanc B.C. Politicheskie ucheniya Drevney Grecii.-M., 1979.

7. Petrov V.R. Deformaciya pravosoznaniya grazhdan Rossii. (Problemy teorii i praktiki): Diss. ... kand. yurid. nauk. - N.Novgorod, 2000. 
Социальные исследования и мониторинг

8. Problemy obschey teorii prava i gosudarstva / Pod. red. B.C. Nersesyanca. - M., 1999.

9. Rad'kov O.S. Pravovoy nigilizm v Rossii. Diss. ... kand. yurid. nauk. - Rostov-na-Donu, 2005.
10. Sorokin V.V. Pravosoznanie v perehodnyy period obschestvennogo razvitiya //Zhurnal rossiyskogo prava. 2002. № 10.

11. Tihonravov Yu.V. Osnovy filosofii prava. Uchebnoe posobie. - M.: Vestnik, 1997. 